\title{
Trust cycle of the finance sector and its determinants: The case of Ukraine
}

\author{
Maryna Brychko \\ Department of Finance, Banking, and Insurance, \\ Sumy State University \\ Ukraine \\ m.brychko@uabs.sumdu.edu.ua
}

\section{Jiří Polách}

Institute of Entrepreneurship and Marketing,

University of Entrepreneurship and Law, Prague, Czech Republic

profpolach@email.cz.

ORCID 0000-0002-2224-0414

\section{Olha Kuzmenko}

Economic Cybernetics, Sumy State University,

Ukraine

o.kuzmenko@uabs.sumdu.edu.ua

\section{Tadeusz Olejarz}

The Faculty of Management,

Rzeszow University of Technology

Poland

olejarz@prz.edu.pl

Abstract. The paper presents the results of exploring the characteristics of trust cycle in the financial sector of the economy in general and across its main components (trust in banking and non-bank financial and credit systems) illustrated by the economy in transition - Ukraine - for the period 1st quarter 2009 - 1st quarter 2018. Determinants of nonlinear dynamics of public trust in the financial sector of the economy were also identified. For this purpose, an algorithm has been developed that enables studying the cyclical nature of public trust in the financial sector and testing the hypotheses about the determinants of its nonlinear dynamics. To highlight the cyclical component of the time series, harmonic analysis via Fourier transformations was used. In order to analyze public trust in the financial sector and its main components the following indicators were used: absolute volatility, relative volatility (in relation to financial and business cycles), the persistence of actual values and cyclic components, correlation with financial and business cycles. Our main

Received: December, 2018 1st Revision: May, 2019

Accepted: November, 2019 (1) $8330.2019 / 12-4 / 20$ 
result is that trust in the banking system has a greater cyclical amplitude than the national economy, the financial sector of the economy, and psychological dimensions of economic agents (a propensity to save and financial savings). High volatility of trust in the banking system indicates that any news or an event could lead to destabilization processes, ignoring of which may lead to a banking crisis.

Keywords: trust cycle, business cycle, financial cycle, economic agent's behaviour.

JEL Classification: E320, E710, G41, O160

\section{INTRODUCTION}

Extensive research has shown that business and financial cycles are highly correlated, especially in the countries that are members of some economic unions as they tied by trade linkages (Charemza et al., 2009; Gazda, 2010 \& 2008; Prince, 2017) or financial integration (Stremmel \& Zsamboki, 2015; Kaminsky \& Reinhart, 2000; Kovacic, \& Vilotic, 2017; Mazur, 2017). The role of the behavioural side of the financial system of the economy for macroeconomic dynamics has also been well-documented empirically and grounded theoretically. Financial booms and busts are driven by behavioural biases that could arise from individual errors, collective biases (for example, contagion effect, and herding behaviour), and generic market inefficiencies (Kahneman \& Tversky, 1979; Kaminsky et al., 2003; Calvo \& Mendoza, 2000, Hadbaa \& Boutti 2019; Vasilyeva et al., 2013). Therefore, financial decisions are often in the grip of "animal spirits", among of which are overconfidence and over-optimism which have been recognized as the most widespread biases provoking financial bubbles and disruptions followed by economic crisis (Balas \& Kaya, 2019).

One major theoretical issue that has dominated this field for many years concerns behavioural biases as a consequence of financial constraints, uncertainty, or periods of stability, and their role in future economic development (Abaas at al., 2018; Yevdokimov \& Melnyk, 2018; Bilan, Vasilyeva \& Lyulyov, 2019; Trojanek, 2010; Kendiukhov \& Tvaronavičiené, 2017; Vasylyeva et al., 2014). Beveridge (1909), Clark (1917), Pigou (1927) and Keynes (1936) were among the first to recognize economic agents' expectations to be essential basic elements for business cycle and economic development. These expectations form the basis for aggregate economic behaviour as they are tied to attitude, trust, opinion or judgment and reflect agent participation in economy through changing consumer demand and investment activity (Dzikevičius \& Vetrov, 2013; 2012; Leśniewski, 2019). Thus, economic development can be attributed to public trust strengthened by the waves of optimism and pessimism in the financial sector. Therefore, it could be argued that business cycle can be investigated through trust cycle due to their synchronization, but with a certain delay in time.

Rational economic determinants, as well as instinctive irrational factors, can generate optimistic expectations about household's incomes growth and, therefore, increase their discretionary costs. Thus, public trust and confidence in future economic development due to the growing household incomes and employment, lead to an increase in consumer spending and investment activity (Kamińska, 2016; Simionescu, 2018). Increase in demand leads to an increase in production and, as a result, in business profitability. Accordingly, subsequent income growth for all interrelated parties (households, business, intermediaries etc.) reinforces the general level of trust. Positive dynamics of revenues' and expenditures' growth creates a peculiar multiplied effect of increasing trust. In economic literature, this phenomenon is known as confidence multiplier, as described by Akerlof and Schiller (2009) on the basis of Keynes' multiplier. Trust will increase if there is no acute social and economic breakdowns. In turn, this tends to 
boost economic activity, therefore, general level of trust contributes to promotion and acceleration of economic growth. Against this background, it is fair to suggest that a certain trust cycle exists, which determines economic development, but with a certain time lag.

It should be mentioned that in contemporary economic research, trust is defined as the key indicator of e-commerce development (Vejačka \& Štofa, 2017) and labor market development (Lazányi \& Bilan, 2017). In addition, the importance of behavioral factors is defined in relation to sustainable development (Mostenska \& Bilan, 2015; Bilan et al., 2019) and market communication (Swiatkiewicz, 2018).

This is the first study to undertake a longitudinal analysis of trust cycle in the financial sector as a whole and for its main components (banking and non-bank financial and credit systems). Characterization of the trust cycle in the financial sector is important for our increased understanding of the reasons behind fluctuations in countries' economies, determining the nature of crises in order to help policymakers to choose the most appropriate measures of monetary and fiscal policies for smoothing or mitigation of cyclic fluctuations.

The rest of the paper is organized in the following way. The second section describes the research methodology adopted for this study. Data and empirical definitions are presented in the third section. The empirical results are presented in Section 4. In Section 5, conclusions and some final remarks are outlined.

\section{METHODOLOGY}

Trust in the financial system is determined by the degree (level) of the economic agents' participation in the financial sector of the economy through the implementation of various types of credit and deposit transactions. Modalities of economic agents' participation are the following: do not trust, and therefore do not participate; trust but do not participate; trust and take part in. Usually, the inability to participate in the financial system is associated with limited disposable income of economic agents. Trusting its own funds to various financial corporations in order to preserve and grow them, society shows both confidence and trust in the domestic financial sector of the economy. Saving funds outside the centralized financial sector of the economy in the form of cash savings in foreign or national currency shows erosion of trust at the institutional (to the national currency, the central bank (the National Bank of Ukraine), individual financial corporations (bank, insurance company, non-state pension fund, etc.)) and system levels (Djalilov et al., 2015; Halbusi \& Tehseen, 2018; Baburina et al., 2017; Buriak et al., 2015; Merenkova \& Boyko, 2009; Kuzmenko \& Koibichuk, 2018, Kuzmenko \& Kyrkach, 2014; Onyshchenko \& Chen, 2017; Luchko et al. 2019; Simionescu, 2019).

Before proceeding the practical formalization of the trust cycle in Ukraine and the identification of their determinants, it should be noted that the determination of relevant research indicators and the formation of further analytical calculations based on them are the basis for obtaining adequate practical calculations. Therefore, it is relevant to study the existing scientific developments in the field of identification of factor characteristics for the financial processes. Thus, methodologies for determining determinants in banking are covered in the works of such scientists as Vasylyeva et al. (2016); Abdul Hadi et al. (2018); Skvarciany et al. (2018), features of processes characteristics in the insurance sphere are described in the papers: Kozmenko and Roienko (2013), Bagmet et al. (2015), Bagmet (2011), and the specificity of identification in the investment field is disclosed in the works: Leonov et al. (2012), Bilan, et al. (2019).

Thorough studies of the determinants of the specific financial processes, namely assessing the financial condition, alternative finance developmen, financial vulnerability are researched by scientists, Sebestova, Majerova and Szarowska, (2018), Bilan, Rubanov, Vasylieva and Lyeonov, (2019) and Blajer-Gołębiewska et al, (2016). According to Boyarko and Samusevych (2011) such intangible assets as company's brand and 
reputation play crucial role in its value growth that confirms importance of behavioral factors influence on the dynamics of economic processes.

Another important step in the formalization of the trust cycle is the study of existing mechanisms for determining the impact of particular economic categories on the development process of others. Thus, interdependence of human capital and remuneration is analyzed in the paper of Bilan et al. (2017), Petrushenko et al. (2017), impact of market interest rates on commercial banks' business is stressed in the work of Rahman et al. (2016), and the relationship between money laundering and efficiency of monitoring of banking transactions is described by such scientists as Leonov et al. (2019), Kostyuchenko et al. (2018).

The next equally important preparatory stage of the study is the choice of mathematical tools for the implementation of the tasks, so on the basis of existing scientific studies in the field the methods of economic and mathematical modeling (Korauš et al. (2019), Oliinyk, (2018), Valaskova et al., (2018), Zachko et al., (2017)) we chose multidimensional statistics and regression analysis.

It should also be noted that the choice of determinants and methods of study should depend on the country for which the model is proposed, since processes in developed and developing countries behave differently. Numerous scientific studies confirm this fact. Thus, the features of developmental stability in Lithuania and Ukraine are investigated in the works of Filipishyna et al. (2018). The specificity of the development of the insurance market in Ukraine compared to European countries is considered in the works of scientists: Kozmenko et al., (2009). The following scientists as Horsch et al., (2018) studied the specifics of deposit insurance systems of post-Soviet countries. The features of attracting investment and developing innovation in developing countries are highlighted in the works of Lobanova et al., (2018) and Kapidani, Luci, (2019). Features of structural changes in transition countries are revealed in the works of such scientists as Olczyk, Kordalska. (2018). The conclusions from the all above mentioned works are reduced to the fact that Ukraine is characterized by a specific flow of financial processes with numerous national peculiarities.

Since the information about the economic agents' expectations is less reliable than factual data, the study proposed to use the formal measure of public trust in the financial sector as a whole and its main components (banking and non-bank financial and credit system) in the form of a relative measure:

$$
A T_{F S}=\frac{D_{F C}}{D I}
$$

where

$A T_{F S}$ is an average trust in the financial sector of the economy;

$D_{F C}$ is the total deposits in financial corporations;

$D I$ is the disposable income.

Thus, the positive dynamics of the average trust growth in the financial sector are achieved by exceeding the growth dynamics of deposits in financial corporations over disposable income. In an unstable state of the economy, turbulence in the financial and financial services markets, insecurity of deposits from inflation, economic agents using a strategy of "wait and see", avoiding financial corporations through the purchase of the real estate, jewelry, cars, etc. that serve an alternative to financial assets. In addition, the marginal value of trust in the financial sector of the economy is calculated:

$$
M T_{F S}=\frac{\Delta D_{F C}}{\Delta D I}
$$

where

$M T_{F S}$ is the marginal trust in the financial sector of the economy; 
$\Delta D_{F C}$ is a change in total deposits in financial corporations;

$\Delta D I$ is a change in disposable income.

Thus, $M T_{F S}$ is the ratio of any change in the deposits of society into the financial corporation to a change in the amount of disposable income, which led to an appropriate change in deposits. As practice shows, the marginal value of trust, as well as the marginal propensity to consumption and savings, is not subject to a rapid change in the short run and is considered as a constant in the end. Therefore, in order to model the cyclicality (nonlinearity) of public trust in the financial sector of the economy and its main components (banking and non-bank financial and credit systems), average trust values will be used.

Similarly, the value of trust in the components of the financial sector of the economy - the banking system and the non-bank financial and credit system - is determined by the ratio of total deposits to deposittaking corporations and other financial corporations to disposable income. The disposable income for calculating public trust indicators is chosen to reflect the economic agents' behavior (based on rational and irrational motives) in terms of the distribution of personal income after the payment of all mandatory taxes and contributions to the state budget of the country. The calculation of average and marginal values of trust is based on the Keynes theory postulates (Keynes, 1936).

The cyclicality of trust in the financial sector of the economy is described as periodically repeating phases (peaks and downturns) of trust during a long period under the influence of objective (rational) and subjective (due to emotional origin) determinants. Such valuations may differ by the nature of origin, duration, and amplitude of oscillations. The duration of the trust cycle in the financial sector is determined by the duration of the stability of the financial system and the economy as a whole. Thus, the longer the periods of financial system instability, the greater the volatility of public trust in this system, and the economy as a whole. The amplitude of cyclical trust fluctuations is not a constant characteristic but depends on the depth of the financial and economic crises and the magnitude of the shocks of economic agents. This means that the greater the losses of households and businesses due to the negative influence of financial sector imbalances, the longer the process of trust restoring and, accordingly, achieving its maximum value (Bilan et al., 2019; Buriak et al., 2015).

Modeling of the cyclical (nonlinear) dynamics of public trust in the financial sector of the economy and its main components (banking and non-bank financial and credit systems) is carried out according to the following algorithm:

1) Identification and selection of long-term trends;

2) Modeling the periodic (cyclic) components of the time series;

3) Normalization of trend and cyclic components of the time series;

4) Analysis of changes in long-term trends.

The identification and selection of the long-term trend is carried out by utilizing the device of the "Trend Line" MS Excel using the determination coefficient. The trend identification is accomplished by preliminary linearization of the desired trend function and estimating its coefficients based on the use of the MS Excel tool "Data, Data Analysis, Regression" adopting the least squares method. Calculation of the periodic (cyclic) component is attained using harmonic analysis via Fourier transform.

Harmonic analysis is based on the position that any dynamic series can be represented as the sum of harmonic components (harmonics). In the general case, their number is not limited. However, the number of calculations of harmonic components could be reduced, in determining a certain degree of accuracy. As a rule, only the harmonics that determine the basic laws of a dynamic series are found. Naturally, the reason for seasonal fluctuations is unimportant for harmonious analysis. The only important thing is that the series 
contains a cyclic component. The methodology for evaluating the cyclic component given below can be used to study any periodic processes and not only cyclic oscillations associated with it.

A prerequisite for an assessment of the periodic component is the exclusion of a regular component (trend). A common approach is to assume that the equation $\left(Y_{t}\right)$ has an additive form:

where

$$
Y_{t}=U_{t}+V_{t}+E_{t}
$$

$Y_{t}$ is the time series value (actual data) at period $\mathrm{t}$;

$U_{t}$ is a deterministic trend-cycle or general movement component;

$V_{t}$ is a deterministic (cyclical) seasonal component;

$E_{t}$ is the irregular (remainder or residual) (stationary) component.

Fourier series expansion of the function $V_{t}$ can be written as

$$
\begin{gathered}
V_{t}=\frac{1}{2} a_{0}+\sum_{k=1}^{\infty}\left(a_{k} \cos k \omega t+b_{k} \sin k \omega t\right) \\
\omega=\frac{2 \pi}{T}
\end{gathered}
$$

where

$a_{k}, b_{k}$ are constants that are called the coefficients of Fourier series;

$\omega$ is a frequency of function;

$k$ is an index of current harmonic.

In general, for the function $Y_{t}$, the following expression (Parseval theorem) could be written

$$
\hat{Y}_{t}=R_{0}+2 \sum_{k=1}^{n-1} R_{k} \cos \left(2 \pi k \frac{t}{T}+\varphi_{k}\right)+R_{k} \cos 2 \pi k \frac{t}{T},
$$

where

$n$ is a number of harmonics;

$$
R_{k}=\sqrt{A_{k}{ }^{2}+B_{k}{ }^{2}}, \quad \varphi_{k}=\operatorname{arctg}\left(-\frac{B_{k}}{A_{k}}\right), \quad A_{k}=R_{k} \cos \varphi_{k}, \quad B_{k}=-R_{k} \sin \varphi_{k}
$$

In order to compare cycles of trust in the financial sector, the banking system and the non-bank financial and credit system, the normalization of cyclic components is carried out. This normalization was prepared by adapting the procedure used by Yakimova (2016).

Normalization was succeed using the following indicator:

$$
c_{t}^{n o r m}=\frac{c_{t}-\underline{c_{t}}}{M A D_{t}}+100
$$

where

$c_{t}^{\text {norm }}$ is a normalized cyclic component of $c_{t}$;

$c_{t}$ is an average number of cyclic components;

$M A D_{t}$ is an average absolute deviation of the row. 
The level of 100 units corresponds to the long-term trend, if $c_{t}^{\text {norm }} \geq 100$ a positive deviation from the long-term trend is obtained, if $c_{t}^{\text {norm }} \leq 100$, the deviation from the long trend is negative.

In order to identify the factors of non-linear (cyclical) development of trust in the financial sector of the economy as a whole and its components, it is proposed to divide all determinants into objective (that are not subject to change, but only adaptation to the functioning of the system), and subjective (that are directly depend on the activity or inactivity of economic agents).

All macroeconomic determinants, having a direct or indirect influence on the state financial policy, are objective factors of cyclical development of trust in the financial sector as a whole and its components, as the economic agent is not able to exert a significant influence on them. However, major factor responsible for macroeconomic stability determine the level of trust in government and all social institutions and, therefore, relate to the trust in the financial sector of the economy and the corresponding imbalances: opportunism, shadow currency market, dollarization, etc.

Subjective determinants include those that directly influence of economic agents on building public trust in the financial sector of the economy and in the cyclical nature of its development. The degree of participation of economic agents in the formation of the resource base of the financial system characterizes the level of trust in it, and therefore reflects the behavior of economic agents in the financial market and the market of financial services.

The behavior of economic agents depends on their propensity to save and consume (Keynes, 1936), which depends on the objective (reducing wages, investment income, increase tax revenues, etc.) and subjective (propensity economic agents to risk, uncertainty, etc.) changes. Accordingly, the average and marginal propensity to save correlated with the relative measure of trust in the financial sector and its components. In this study, there is a propensity to save and propensity to save in financial assets (also referred as propensity to personal financial savings).

The following indicators were used for calculating the average and marginal propensity to save

$$
A P S=\frac{S}{D I}
$$

where

$A P S$ is an average propensity to save;

$S$ is an amount of savings;

$D I$ is a disposable income.

Where

$$
M P S=\frac{\Delta S}{\Delta D I}
$$

$M P S$ is a marginal propensity to save;

$\triangle S$ is a change in total savings;

$\triangle D I$ is a change in disposable income.

The tendency of economic agents to save money is a steady pattern of behavior that characterizes pessimistic/optimistic expectations based on an assessment of the current state and prospects of the country's economic development.

The average and marginal propensity for financial savings reflects the behavior model and the level of trust in the financial sector of the economy. The following formulas were used: 
where

$$
A P F S=\frac{F S}{D I}
$$

$A P F S$ is an average propensity for financial savings;

$F S$ corresponds to financial assets.

$$
M P F S=\frac{\Delta F S}{\Delta D I}
$$

where

$M P F S$ is a marginal propensity for financial savings;

$\triangle F S$ is a change in financial savings (growth of financial assets).

Based on the main psychological law, in the phase of economic recovery, when the growth of income takes place, the propensity to save dominated over consumer motives of economic agents. However, destabilizing processes in the national economy lead to a change in the psychological patterns of behaviour, and, accordingly, the proportion between consumption and savings, including financial assets, is violated towards the growth of the first in the total capital.

The calculation of absolute volatility makes it possible to evaluate the oscillation amplitude of the public trust in the financial system of Ukraine. Absolute volatility is measured by the following formula:

$$
V_{t}^{a}=\frac{\max _{t} y_{t}-\min _{t} y_{t}}{S}
$$

where

$V_{t}^{a}$ is absolute volatility;

$y_{t}$ is a time series;

$S$ is a mean square deviation of the time series.

Relative volatility was calculated as the ratio of the absolute volatility of trust in the financial sector to the absolute volatility of real GDP and the weighted average hryvnia exchange rate in the interbank foreign exchange market.

In order to test the hypothesis of long-term trust in the financial sector (persistence calculation), the Hurst indicator was used:

$$
\frac{R}{S}=(\alpha \cdot N)^{H},
$$

where

$H$ is Hurst index;

$N$ is a number of observation periods.

Wherefrom

$$
H=\frac{\log \left(\frac{R}{S}\right)}{\log (\alpha \cdot N)}
$$

where the scale of the accumulated deviation:

$$
R=\max _{1 \leq u \leq N} Z_{u}-\min _{1 \leq u \leq N} Z_{u}
$$




$$
Z_{u}=\sum_{1}^{u}\left(y_{i}-\bar{y}\right)
$$

where $\bar{y}$ - the arithmetic mean value of the time series.

In accordance with the obtained values of the Hurst index $(\mathrm{H})$, the following types of time series are distinguished:

a) persistent $(0.5<\mathrm{H}<1)$;

b) $\operatorname{random}(\mathrm{H}=0,5)$;

c) anti-imperative $(0<\mathrm{H}<0,5)$.

In the case when the Hurst index is equal to 0.5 , the economic process is represented by the random walk of values, which is why it is difficult to predict such phenomena and processes, since any chosen model will be inadequate.

Persistent time series is called trend-stable time series, since the high values of the Hurst index (approximating to the nearest one) indicate a tendency that will coincide in the future. That is, if the analyzed process grew (declined) in the previous period, then there is a high probability that this tendency will persist for some time in the future. Persistent time series have a long-term or long memory, that is, all events, even those that took place in the distant past, have the same effect on the current state. However, it should be noted that during periods of uncertainty and turbulence some time series could become random or antiimperative, that is, to lose "memory".

The degree of synchronization of the change in indicators relative to business and financial cycles is measured using the correlation coefficient.

Indicators are:

a) procyclical, if they change in the same direction as the business / financial cycle - contemporaneous correlation coefficient $(p(0))$ is positive (greater than zero);

b) counter-cyclical if they move in opposite directions, that is, the contemporaneous correlation coefficient is negative (less than zero);

c) acyclic if they do not correlate with each other, that is, $p(0)=0$.

The coefficient of mutual correlation (contemporaneous correlation coefficient) also makes it possible to analyze the cyclical determinants of trust in the financial sector as a whole and its main components (trust in banking and non-bank financial and credit systems) in terms of their synchronization. Such analysis provides a baseline for finding out what determinants are ahead of the trust cycle for $i$ periods (the highest value of the coefficient of mutual correlation is obtained for the negative value $\imath$ ); coincident (synchronized with a loop) if the value of the correlation coefficient is obtained when $i=0$; delayed from cycle to $i$ periods (the highest value of the correlation coefficient is obtained for a positive value $\imath$ ).

The study of cyclical dynamics of trust in the financial sector of the Ukrainian economy focuses on the time series of five groups of determinants that need to be considered in the dynamics: macroeconomic indicators (both objective and subjective estimates of the growth of the national economy and personal well-being), indicators of the financial sector of the economy (as measures of confidence in the financial stability of the country), indicators of regulatory policy (as an assessment of the macroeconomic policy stability), indicators of the external sector of the economy (as measures of foreign economic stability of the country's economy) and indicators of consumer behavior (as a pessimistic / optimistic assessment of the prospects of economic and financial sector development).

The information basis for the study is quarterly data for the period 1st quarter 2009 - 1st quarter 2018. The following groups of indicators were used:

- macroeconomic indicators: indices of real GDP, real wages and inflation (consumer price index), average monthly salary per one employee, unemployment rate, gross external debt, level of GDP 
redistribution through the consolidated budget of Ukraine, international reserves, available income, savings, financial assets. The source of the data was the official data of the State Statistics Service of Ukraine (Ukrstat);

- indicators of the financial sector of the economy: currency and deposits in financial corporations, deposit-taking corporations and other financial corporations, the weighted average rate on the interbank foreign exchange market of Ukraine, refinance loans granted by the National Bank of Ukraine to regulate banks' liquidity, residential real estate loans to total gross loans. The database was created from the open official data of the National Bank of Ukraine.

Input data for public trust measures were the quarterly values of the total amount and the growth of currency and deposits to financial, deposit-taking and other financial corporations taken from the open official data of the National Bank of Ukraine; the total amount and the growth in disposable income taken from the official data of the State Statistics Service of Ukraine (Ukrstat) for the period from 1st quarter of 2009 until 1 st quarter of 2018.

The real GDP reflects the overall economic development of the country over a period that determines the level of the financial potential of economic agents. This index serves as a general indicator of the objective assessment by economic agents of the national economy growth, or, conversely, its decline during periods of turbulence and the manifestations of crisis in the economy. Economic agents are inclined to increase the level of public trust in the financial system based on statistical information and forecast scenarios on the growth of the national economy that results in the increase of deposit-credit operations of a wide range of economic agents. Conversely, the tendencies of economic fluctuations to fade lead to a decline in the general level of public trust in the financial sector.

The average monthly wage per employee and the real wage index determine the purchasing power of economic agents, their ability to maintain a standard of living and the potential for investment. Real GDP is an objective assessment of the dynamics of public welfare, conversely, the real wage index serves as an objective indicator of the personal economic well-being of economic agents. The average monthly salary is a subjective assessment of the personal economic well-being of economic agents. Therefore, economic agents do not always act rationally, and their behavior is usually formed under the influence of "animal spirits" (feelings, emotions, mood, etc.). This fact indicates that the decision to cover current consumer needs or savings, including in the form of investments in the financial sector of the economy, is based on a sufficient level of trust (Keynes, 1936). It should be noted in this context that the confidence of economic agents in the future is whether a part of the overall level of public trust. That is why, the objective and/or subjective decline in the incomes of economic agents, leads to a decrease in public trust in the future country's economy as a whole and in the financial sector of the economy, in particular.

The unemployment rate could serve as an objective measure of macroeconomic stability of the country. Thus, pessimistic expectations concerning the growth of the unemployment rate according to the emergency motive may lead to an increase in the propensity of economic agents to save. These savings could be in the form of investments in the financial sector of the economy, thus multiplying public trust in the financial sector. Conversely, savings could be carried out bypassing the financial system in the form of cash savings of economic agents. The last is a confirmation of a general pessimistic assessment by economic agents of the macroeconomic situation in the country, and, correspondingly, the trust crisis in the main social institutions.

The inflation rate (Consumer Price Index) and the weighted average hryvnia exchange rate in the Ukrainian interbank foreign exchange market (devaluation/revaluation of hryvnia) are indicators of financial stability in the country. In the current economic climate of Ukraine, economic agents' expectations of significant inflation and devaluation of national currency are relentlessly forcing to the suspension and 
dissolution of trusting relations with the financial system causing an early withdrawal of deposits and their consumption for the purchase of imported goods of long-term use or their transfer to foreign currency.

The volume of refinance loans granted by the National Bank of Ukraine to regulate banks' liquidity has a significant effect on the formation of trust or its erosion. Typically, NBU operations on liquidity regulation of banking institutions are considered as warning signals of turbulence in the banking system, and therefore information on providing overnight loans or refinancing loans to banks through a permanently operating refinancing line causes a panic of economic agents. Moreover, the processes of regulation of banks' liquidity is not direct evidence of troubled banking systems, but contentious information in media, untimely and inadequate response of state regulators, as well as the low level of literacy among the people, leads to a drop in the level of public trust in the banking system and the financial sector as a whole.

The growing volume of residential real estate loans in total gross loans of the banking system indicates optimistic expectations of society concerning the potential development of the country's economy and the financial sector in particular. On the one hand, loans to households for the purchase, construction, and reconstruction of real estate can characterize the level of trust to the financial sector of the economy. On the other hand, taking into account the significance informal links and importance of the recommendations of the trustees, the rumors concerning poor service of these loans (banking institutions fraud regarding the terms of the credit agreement, resale of the client's debt to the other agents etc.) leads to a drop in public trust in the financial sector of the economy.

The level of GDP redistribution through the consolidated budget makes it possible to evaluate the level of centralization of the public finance system. Inefficient and inappropriate redistribution of GDP pushes taxpayers to conceal their incomes that circumvent the financial system of the country. In the case when the level of redistribution of GDP is inversely related to the degree of economic agents' well-being, the level of public trust is low, provoking social and political discontent in society. Thus, it can be argued that compliance with the optimal level of GDP redistribution through the consolidated budget drives positive expectations, consumer sentiments, business and investment climate, and, therefore, determines trust to all governmental institutions, including the Central bank and the financial sector of the economy as a whole.

Any changes in the country's external debt and the volume of international reserves could be viewed as signals of the currency crisis. Rumors, discussions and alarming predictions about increased external borrowing and insufficiency of international reserves spread on the Internet and through the mass media aggravates social tension and speculative frenzies in the foreign exchange market. Moreover, the inefficient use of public debts slows down the growth of the country's economy, causes a reduction in public spending on social and investment sphere, increases the country's dependence on international financial institutions, reducing the autonomy of the state's financial policy, creating destructive processes in social sentiments. Another key point is that often the problems of the state in the field of regulation of external debt and international reserves are associated with a high probability of a financial crisis. And, therefore, it essentially affects the level of public trust in the financial sector of the economy acting as the determinants of its nonlinear cyclical development.

\section{EMPIRICAL RESULTS AND DISCUSSION}

As a result of the filtration it was found that trust in the financial sector of the economy and the banking system is represented by a polynomial of degree 3 . The latter means that during the research period (1st quarter 2009 to 1 st quarter 2018), the trend had changed its direction twice ( 2 bends of the curve) under the influence of several processes (Figure 1a and 1b). This demonstrates that incrementation to trust in the financial sector of the economy and banking system has changed twice, that is, during the analyzed period, 
both the crisis of trust and its restoration have been observed. Moreover, the greatest reduction in the level of trust in the financial sector of the economy in general and the banking system, in particular, was observed in the 3rd quarter of 2012, which complements to the general economic recession in the country.

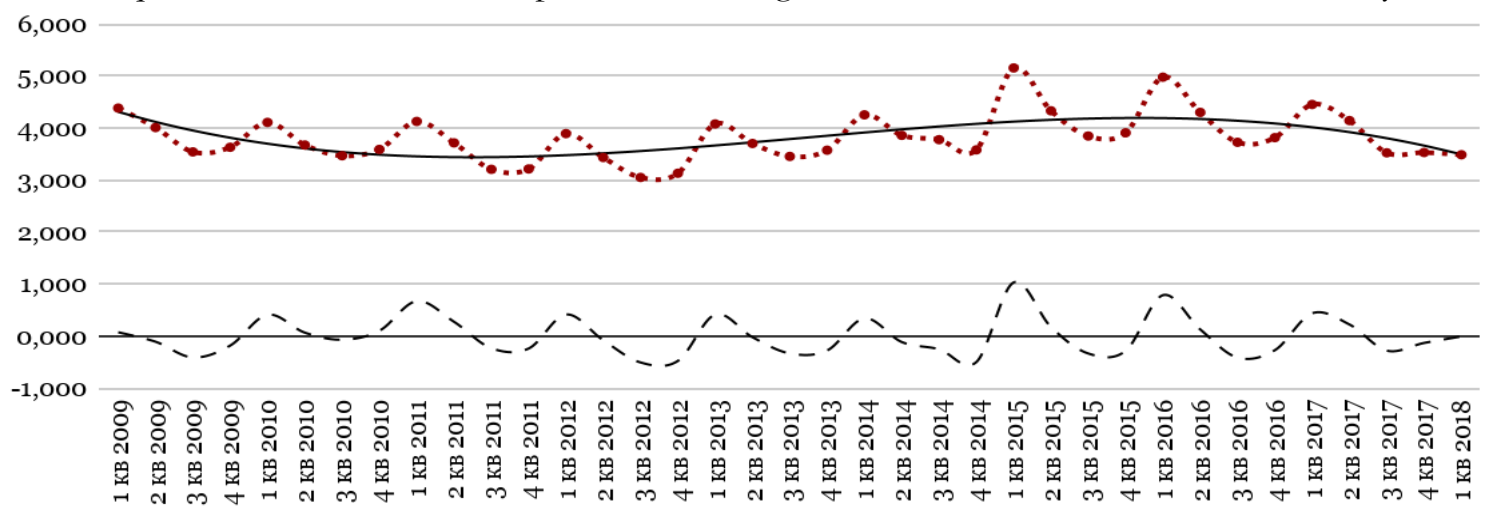

Trust in the financial system

\section{Trend - Cyclic components}

a

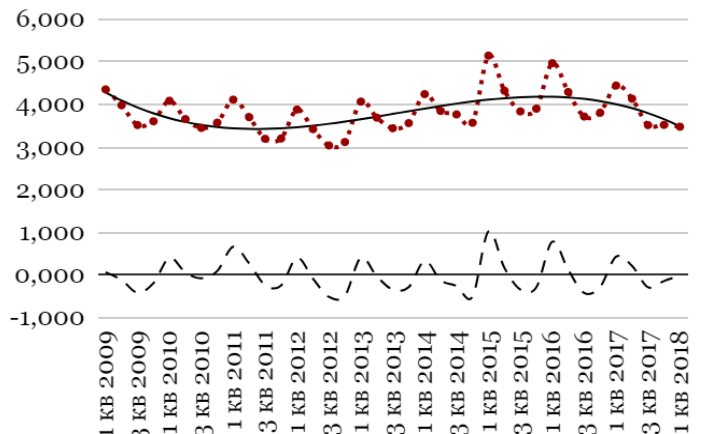

Trust in the banking system

- Trend

Cyclic components

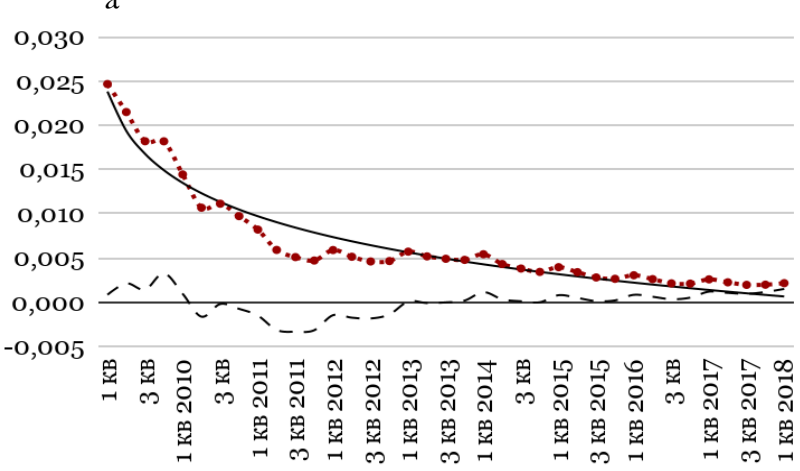

Trust in the non-banking financial and credit system

- Trend

Figure 1. Actual value, trend and cyclic patterns of trust to (a) the financial sector of the economy of Ukraine, (b) the banking system, (c) the non-banking financial and credit system

Source: Calculations based on the data from The State Statistics Service of Ukraine (Ukrstat), National bank of Ukraine

The analysis also shows a declining of long-term movement (trend) of public trust in the non-banking financial and credit system with unstable cyclical variations around it (Figure 1c). During the analyzed period of the 1st quarter of 2009 - 1st quarter of 2018, the highest value trust in the non-banking financial and credit system had reached in the 1 st quarter of 2009 . Since the 1 st quarter of 2009 , there was a decline. This corresponds to the general economic recession in Ukraine and the world as a result of the negative influence of the financial crisis in 2008. The same tendencies can be observed in respect of other economic and financial phenomena and processes that scholars have pointed out. However, in contrast to the economic recovery in 2010-2011, trust in the non-banking financial and credit institutions has not recovered, but continued the declining trend and, since the 2 nd quarter of 2016, has reached its minimum value. Thus, under the influence of the crisis phenomena and processes of 2008, trust in non-banking financial and credit institutions in comparison with trust to the banking system suffered large losses, which can be explained by 
scarce liquidity and insecurity of insurance savings and other financial instruments in comparison with deposit investments.

The dynamics of normalized cyclical movements of trust in the financial sector of the economy, the banking system and the non-bank financial and credit system is shown in Figure 2.

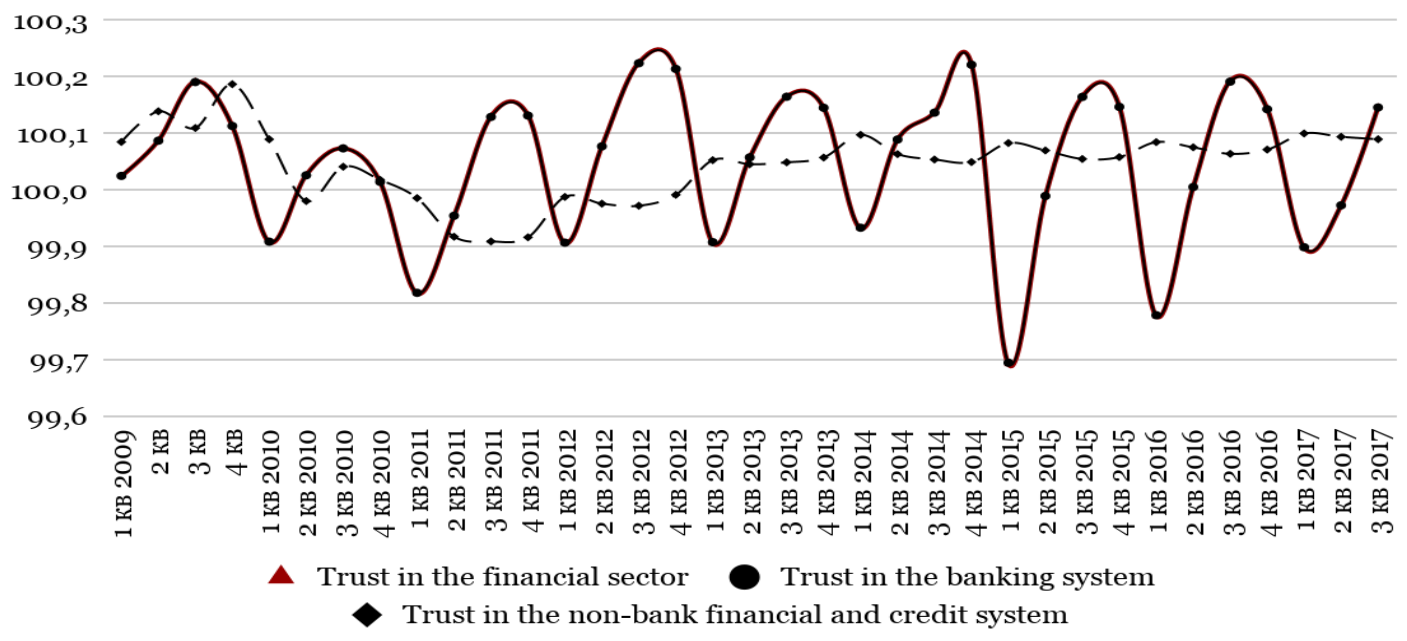

Figure 2. Dynamics of normalized cyclical movements of trust indicators

Source: Calculations based on the data from The State Statistics Service of Ukraine (Ukrstat), National bank of Ukraine

The visual analysis of cyclical movements (Figure 2) provides a basis for the following empirical conclusions. Trust in the non-bank financial and credit system from the 2nd quarter of 2010 to the 4th quarter of 2013 has a negative deviation from the long-term trend, and from 1 quarter of 2014, it fully responds to it. While trust in the financial sector of the economy and the banking system is characterized by highly volatile trends. Normalized cyclical movements of trust in the financial sector of the economy and trust in the banking system have a close direct correlation between their cycles. In this case, the high value of the correlation coefficient $(0,990)$ confirms the significant synchronization of two cycles. This can be explained by the fact that deposit-taking corporations occupy a significant share of the financial sector of the economy. Normalized cyclical movements of trust in the financial sector of the economy and trust in the non-bank financial and credit system have a reverse relationship. Particularly prominent in this area is the achievement of the maximum level of trust in the financial sector of the economy (peak of the cycle) and the corresponding minimum level of trust in the non-bank financial and credit system (bottom of the cycle) during the crisis periods of the economic development. This may reflect the fact that in terms of financial resources allocation, deposit-taking corporations and other financial corporations act as substitutes, and, accordingly, the loss of trust in the non-bank financial and credit system is offset by a growing trust in banking institutions.

The results of the public trust volatility assessment (Table 1) provide grounds for affirming that among the calculated indicators, the lowest volatility is reflected in the trust in the non-bank financial and credit system, which testifies to small fluctuations of trust during the analyzed period. Trust in the banking system has a greater cyclical amplitude than the national economy (real GDP, real wage index, average monthly salary per one employee, unemployment rate, etc.), the financial sector of the economy (inflation rate, volume of refinance loans granted by the National Bank of Ukraine, weighted average hryvnia exchange rate, etc.), and a propensity to save and financial savings. The high volatility of trust in the banking system 
indicates that any news (the jump in the national currency exchange rates) or an event (the introduction of a temporary administration or the liquidation of a banking institution) could lead to destabilization processes, ignoring of which may lead to the banking crisis. The volatility of trust in the financial sector of the economy (which has a higher cyclical amplitude than all the analyzed macroeconomic indicators, excluding the real GDP, inflation rate and the level of GDP redistribution through the consolidated budget of Ukraine) is associated with certain crisis processes and reflects the uncertainty of actors of the financial system in its stability.

Table 1

Estimation of absolute and relative volatility of trust in the financial sector of the economy

\begin{tabular}{|l|c|c|c|}
\hline \multirow{2}{*}{} & \multirow{3}{*}{ Volatility } \\
\cline { 3 - 4 } & absolute & $\begin{array}{c}\text { relative } \\
\text { business } \\
\text { cycle }\end{array}$ & $\begin{array}{c}\text { financial } \\
\text { cycle }\end{array}$ \\
\hline Real GDP & 6,143 & 1,000 & 2,565 \\
\hline Real wage index & 3,567 & 0,581 & 1,489 \\
\hline Average monthly salary per one employee & 3,625 & 0,590 & 1,513 \\
\hline Unemployment rate & 4,061 & 0,661 & 1,695 \\
\hline Inflation rate & 6,144 & 1,000 & 2,565 \\
\hline $\begin{array}{l}\text { The volume of refinance loans granted by the National Bank of } \\
\text { Ukraine }\end{array}$ & 4,380 & 0,713 & 1,829 \\
\hline $\begin{array}{l}\text { Weighted average hryvnia exchange rate in the Ukrainian interbank } \\
\text { foreign exchange market }\end{array}$ & 2,395 & 0,390 & 1,000 \\
\hline $\begin{array}{l}\text { The volume of residential real estate loans in total gross loans of the } \\
\text { banking sector }\end{array}$ & 3,353 & 0,546 & 1,400 \\
\hline Gross external debt & 3,613 & 0,588 & 1,508 \\
\hline Level of GDP redistribution through consolidated budget of Ukraine & 6,293 & 1,024 & 2,627 \\
\hline International reserves & 3,637 & 0,592 & 1,518 \\
\hline The average propensity to save & 4,998 & 0,814 & 2,087 \\
\hline Marginal propensity to save & 5,478 & 0,892 & 2,287 \\
\hline The average propensity to financial savings & 5,721 & 0,931 & 2,388 \\
\hline Marginal propensity to financial savings & 5,928 & 0,965 & 2,475 \\
\hline Trust in the financial sector & 5,910 & 0,962 & 2,467 \\
\hline Trust in the banking system & 6,370 & 1,037 & 2,660 \\
\hline Trust in the non-bank financial and credit system & 4,327 & 0,704 & 1,807 \\
\hline
\end{tabular}

Source: Calculations based on the data from The State Statistics Service of Ukraine (Ukrstat), National bank of Ukraine

According to the above data, it can be argued that trust in the banking system and the financial system as a whole is almost equally volatile as the business cycle in the country (table 2). At the same time, the volatility of trust in a non-bank financial and credit system is 30\% less than the volatility of the business cycle in Ukraine. This reflects the fact that during the last decade there is relative stability of the level of trust in the non-bank financial and credit system. And, although according to previous studies, the overall level of trust in insurance companies, credit unions, investment companies and other financial intermediaries of the non-bank financial and credit system is decreasing, the amplitude of these changes is insignificant, especially compared to the dynamics of GDP changes.

The volatility of trust to the financial sector in general and its components in particular with regard to the financial cycle of the country is higher at almost 2-2.5 times. Excessive volatility that was admitted may 
indicate that in the case of public authorities' omissions with regard to mitigation variability of public trust in the financial sector caused by the financial cycle can mutually reinforce these fluctuations.

Calculated persistence values based on the Hurst index are given in table 2.

Table 2

Persistence of actual values and cyclical components of public trust in the financial sector of the economy

\begin{tabular}{|c|c|c|}
\hline & \multicolumn{2}{|c|}{ Persistence } \\
\hline & $\begin{array}{l}\text { actual } \\
\text { values }\end{array}$ & $\begin{array}{c}\text { cyclic } \\
\text { components }\end{array}$ \\
\hline Real GDP & 0,456 & 0,458 \\
\hline Real wage index & 0,284 & 0,325 \\
\hline Average monthly salary per one employee & 0,261 & 0,327 \\
\hline Unemployment rate & 0,242 & 0,335 \\
\hline Inflation rate & 0,415 & 0,416 \\
\hline The volume of refinance loans granted by the National Bank of Ukraine & 0,281 & 0,386 \\
\hline $\begin{array}{l}\text { Weighted average hryvnia exchange rate in the Ukrainian interbank foreign } \\
\text { exchange market }\end{array}$ & 0,120 & 0,275 \\
\hline $\begin{array}{l}\text { The volume of residential real estate loans in total gross loans of the banking } \\
\text { sector }\end{array}$ & 0,159 & 0,361 \\
\hline Gross external debt & 0,196 & 0,248 \\
\hline Level of GDP redistribution through consolidated budget of Ukraine & 0,495 & 0,425 \\
\hline International reserves & 0,242 & 0,343 \\
\hline The average propensity to save & 0,396 & 0,407 \\
\hline Marginal propensity to save & 0,461 & 0,494 \\
\hline The average propensity to financial savings & 0,433 & 0,480 \\
\hline Marginal propensity to financial savings & 0,560 & 0,541 \\
\hline Trust in the financial sector & 0,484 & 0,262 \\
\hline Trust in the banking system & 0,488 & 0,263 \\
\hline Trust in the non-bank financial and credit system & 0,265 & 0,319 \\
\hline
\end{tabular}

Source: Calculations based on the data from The State Statistics Service of Ukraine (Ukrstat), National Bank of Ukraine

Trust in the financial sector of the economy as a whole, as well as its structural components, is represented by anti-persistent time series. This suggests that trust in the financial system of the country is highly variable, that is, if the system in the previous period showed growth of public trust, then it is likely that in the next period there will be a recession or a trust crisis. The low persistence of cyclical movements of trust in the financial sector of the economy suggest that the investigated process consists of frequent changes in the boom and bust. That is why such time series are sensible to any information (true or false) concerning the main indicators of the banking institutions' activities (change in ownership of systemically important bank, liquidity problems, introduction of the NBU's temporary administration, etc.) and/or 
changes in the current characteristics of the financial system (devaluation of the national currencies, interest rate changes, restrictions on currency transactions, etc.), which may lead to a change in the phase of the trust cycle in the financial sector of the country.

The study found that trust in the banking system is a procyclical indicator in relation to both business and financial cycles, indicating the synchronicity of their changes (tends to increase during the period of economic and financial upsurge (expansion) and tend to decrease in the corresponding phase of the fall (recession)). The calculations also led to an ambiguous conclusion that trust in the financial system does not depend on the ups and downs of the financial cycle (acyclic indicator), but it is a procyclical indicator relative to the business cycle. An acyclic behavior of trust in the financial system in relation to the financial cycle could be explained by its multidimensionality and high volatility. That is why, in the phase of the financial cycle recession, the trust of economic agents may be invariant, that is, to grow under the influence of irrational factors or to decrease as a result of the rational behavior of the economic agents.

Table 3

Correlation between trust in the financial sector of the economy and business and financial cycles

\begin{tabular}{|l|c|c|c|c|}
\hline \multirow{2}{*}{} & \multicolumn{2}{|c|}{$\begin{array}{c}\text { Relationships to the } \\
\text { business cycle }\end{array}$} & \multicolumn{2}{c|}{$\begin{array}{c}\text { Relationships to the } \\
\text { financial cycle }\end{array}$} \\
\cline { 2 - 6 } & $p(0)$ & indicator type & $p(0)$ & indicator type \\
\hline Real GDP & 1,000 & procyclical & 0,271 & procyclical \\
\hline Real wage index & $-0,347$ & countercyclical & $-0,028$ & acyclic \\
\hline Average monthly salary per one employee & 0,051 & acyclic & 0,862 & procyclical \\
\hline Unemployment rate & 0,409 & procyclical & 0,270 & procyclical \\
\hline Inflation rate & 0,710 & procyclical & 0,213 & procyclical \\
\hline The volume of refinance loans granted by the & & & & \\
National Bank of Ukraine & 0,157 & acyclic & 0,836 & procyclical \\
\hline $\begin{array}{l}\text { Weighted average hryvnia exchange rate in the } \\
\text { Ukrainian interbank foreign exchange market }\end{array}$ & 0,271 & procyclical & 1,000 & procyclical \\
\hline $\begin{array}{l}\text { The volume of residential real estate loans in total } \\
\text { gross loans of the banking sector }\end{array}$ & $-0,017$ & acyclic & $-0,660$ & countercyclical \\
\hline Gross external debt & $-0,055$ & acyclic & $-0,157$ & acyclic \\
\hline $\begin{array}{l}\text { Level of GDP redistribution through consolidated } \\
\text { budget of Ukraine }\end{array}$ & $-0,133$ & acyclic & $-0,157$ & acyclic \\
\hline International reserves & $-0,351$ & countercyclical & $-0,717$ & countercyclical \\
\hline The average propensity to save & $-0,223$ & countercyclical & $-0,479$ & countercyclical \\
\hline Marginal propensity to save & $-0,005$ & acyclic & 0,060 & acyclic \\
\hline The average propensity to financial savings & $-0,051$ & acyclic & $-0,593$ & countercyclical \\
\hline Marginal propensity to financial savings & $-0,319$ & countercyclical & $-0,175$ & acyclic \\
\hline Trust in the financial sector & 0,406 & procyclical & 0,091 & acyclic \\
\hline Trust in the banking system & 0,538 & procyclical & 0,307 & procyclical \\
\hline Trust in the non-bank financial and credit system & 0,003 & acyclic & $-0,576$ & countercyclical \\
\hline
\end{tabular}

Source: Calculations based on the data from The State Statistics Service of Ukraine (Ukrstat), National bank of Ukraine

Trust in a non-bank financial and credit system is a countercyclical indicator relative to the financial cycle, that is, tend to increase when the financial cycle is slowing down and is acyclic in relation to the business cycle. This is evidence that economic growth in the country will not increase or decrease the participation of economic agents in non-bank financial and credit system; however, in turbulence conditions in the financial market (the financial cycle has a negative dynamics), the credibility of members of the non- 
bank financial and credit system will grow, and therefore they will act as an alternative source of investment in financial resources. That means trust in non-bank financial and credit system tends to do well while the financial system as a whole is doing poorly.

All cyclical determinants of trust in the financial sector as a whole and its main components (trust in banking and non-bank financial and credit systems) have been classified into three categories in terms of their synchronization, that is, according to the timing of their changes in relation to how public trust in the financial sector and its components changes (Appendix A).

Thus, real GDP (4 quarters), real wage index ( 2 quarters), gross external debt (4 quarters), and marginal propensity to save (3 quarters) are defined as leading (signal) indicators that change with some time ahead of cyclical fluctuations of public trust in the financial system and serve as a signal of erosion of public trust in the financial sector of the economy. The unemployment rate, inflation rate and the level of GDP redistribution through the consolidated budget of Ukraine are coincident indicators, that change at approximately the same time as the trust in the financial sector of the economy, thereby providing information about the current state (the existence of the crisis of trust in the financial sector). An average monthly salary per one employee, weighted average hryvnia exchange rate in the Ukrainian interbank foreign exchange market, volume of residential real estate loans in total gross loans of the banking sector, average propensity to save and marginal propensity to financial savings (4 quarters), volume of refinance loans granted by the National Bank of Ukraine and international reserves ( 3 quarters) are defined as lagged economic indicator that does not change direction until a few quarters after the public trust does. Information about these determinants is more useful to confirm the turning points and other specific patterns of the trust cycle.

The signal indicators of the erosion of trust in the banking system are real wage index ( 2 quarters), marginal propensity to save ( 3 quarters), inflation rate ( 4 quarters), international reserves ( 4 quarters), and marginal propensity to financial savings (4 quarters). Real GDP, unemployment rate, level of GDP redistribution through the consolidated budget of Ukraine and an average propensity to save moves at the same time the public trust does, that is why could characterize the current state of trust in the banking system. Other determinants that are not included in the previous two groups are lagged and characterize the results of changes in the level of trust in the banking system.

Leading indicators of the loss of public trust in the non-bank financial and credit system include: real GDP (3 quarters), average monthly salary per one employee (4 quarters),volume of refinance loans granted by the National Bank of Ukraine ( 3 quarters), gross external debt (1 quarter), average (4 quarters) and marginal (1 quarter) propensity for financial savings. The current level of trust in the non-bank financial and credit system is characterized by the following determinants: real wage index, unemployment rate, the volume of residential real estate loans in total gross loans of the banking sector, and average propensity to save. All other indicators are lagged trust determinants in the non-bank financial and credit system and tend to increase for 1 or 4 quarters after the public trust starts to restore.

\section{CONCLUSION}

Filtration revealed that the trust in the financial sector of the economy and the banking system does not have uniformly accelerated growth or reduction in their levels. The results of this research support the idea that trust in the financial sector of the economy is inherently fragile and unstable. The findings of this study also indicate serious deterioration in the crisis of public trust in non-banking financial and credit institutions due to their inability to fulfill their obligations and, as a result, the disorganization of the financial sector and an increase in social tension. The practical implication of the following results indicated that given the lack of extensive experience of economic agents with insurance companies, non-state pension 
funds, investment companies in Ukraine, without significant changes in the regulatory policy to improve the functioning of these institutions, the level of trust in the non-banking financial and credit system will remain at an extremely low level.

Based on normalized cyclical movements of trust in the financial sector of the economy and trust in the banking system, this study has identified significant synchronization of their cycles. Therefore, all suggestions and recommendations for changes in financial policy would have an equal effect on restoring public trust in the financial sector of the economy as a whole, and the banking system in particular. By contrast, the achievement of the maximum level of trust in the banking sector of the economy corresponds to a minimum level of trust in the non-bank financial and credit system. For this reason, various instruments and frameworks of monetary policy aimed at regulating imbalances in the development of the banking system do not promote the growth of trust in other financial corporations, which economic agents consider as an alternative to the allocation of financial resources.

This study has also identified low volatility of the trust in the non-bank financial and credit system, which testifies to small fluctuations of trust during the analyzed period. However, at the same time, trust in the banking system has a greater cyclical amplitude than indicators macroeconomic and financial sector development and stability. This latter finding indicates that trust in the banking system is very sensitive to any even minor negative news or event could trigger trust crisis, ignoring of which could create other types of crises such as economic or financial. During the last decade, trust in the banking system and the financial system as a whole is almost equally volatile as the business cycle in the country, whereas trust in the nonbank financial and credit system is relatively stable. The most obvious finding to emerge from this study is that volatility of trust to the financial sector in general and its components, in particular, is twice as high as financial cycle volatility that could be explained by the fact of generally longer duration and higher amplitude of financial cycles in regards to the business cycle. The research has also shown that trust in the financial sector of the economy as a whole, as well as its structural components, is highly variable and anti-persistent, and therefore consists of frequent changes in the boom and bust. This finding is confirmed that trust in the financial sector of the economy is very inert to panic irrational behavior under the influence of pessimistic sentiments during the crisis period.

Understanding the role of trust in the financial sector of the economy as a whole, as well as its structural components (banking and non-bank financial and credit system) is a key for financial policy design. Procyclical nature of trust in the banking system can help to identify risks of a financial and economic crisis in the future. Authorities could use measures of trust in the banking sector to better identify risks of financial and economic crisis, due to the synchronicity of their changes. As such, policymakers could enhance trust in the banking system in order to build buffer during financial and economic upsurge that could be utilized during a recession, thereby ensuring stabilization of financial system and an economy as a whole.

General external debt defined as leading indicators that change 4 quarters ahead of cyclical fluctuations of public trust in the financial system as well as its main components and serve as a signal of erosion of public trust. Therefore, general external debt could be used for short term predictions of trust cycle developments, since they begin to decline before the trust in the financial sector falls into a recession and vice versa. The unemployment rate changes at approximately the same time as the trust in the financial sector of the economy, thereby providing information about the existence of the crisis of trust in the financial sector of the economy and its components, whereas the weighted average hryvnia exchange rate in the Ukrainian interbank foreign exchange market does not change direction until four quarters after the public trust does. Moreover, depreciation in the exchange rate only confirms the bust of the trust cycle, in other words - trust crisis. Real wages and marginal propensity to save reach their minimum value before the crisis of trust in the financial sector in general and the banking system, in particular, take place. That is why the effective cessation of decline in objective incomes and the pessimistic sentiments of economic agents, 
through appropriate changes in the country's financial policy, would slow down the erosion of public trust. This new understanding should help to improve predictions of the trust crisis.

The findings from this study make several contributions to the current literature. This project is the first comprehensive investigation of the trust cycle in the financial system of the economy as a whole, as well as its structural components (banking and non-bank financial and credit system). This paper establishes a quantitative framework for detecting and evaluating stylized facts over the period 2009-2018 focusing on trust cycle volatility, persistence, and synchronization with financial and business cycles. This study provides a baseline for detecting leading, coincident or lagging cyclical determinants of trust in the financial sector.

This research has thrown up many questions in need of further investigation. In order to form an effective governmental counter-cyclical policy in the management of economic agent's expectations, the initial screening specification of trust cycles (trust in the financial sector, the banking system, non-bank financial and credit system) is strongly recommended. Future research could also be conducted to determine the local minimum and maximum of cyclic variation curve, the number of peaks, average phase-amplitude (upturn and downturn) and cumulative phase shift (upturn and downturn). Other areas of research to be encouraged include developing a semi-structural model in order to explain macro-financial linkages of business, financial and trust cycles addressing both short- and medium-term developments.

\section{ACKNOWLEDGEMENT}

This work would not have been possible without the financial support of the Ministry of Education and Science of Ukraine. The paper was prepared as part of the Young Scientist Research on the topic "Economic-mathematical modeling of the mechanism for restoring public trust in the financial sector: a guarantee for economic security of Ukraine" (registration number 0117U003924).

\section{REFERENCES}

Abaas, M. S. M., Chygryn, O., Kubatko, O., \& Pimonenko, T. (2018). Social and economic drivers of national economic development: The case of OPEC countries. Problems and Perspectives in Management, 16(4), $155-168$. https://doi.org/10.21511/ppm.16(4).2018.14

Abdul Hadi A.R., Hussain H.I., Suryanto T., \& Yap T.H. (2018). Bank`s performance and its determinants - Evidence from middle eastern Indian Sub-continent and African bank`s. Polish Journal of Management Studies, 17(1), 17-26. https://doi.org/10.17512/pjms.2018.17.1.02

Akerlof, G., \& Shiller, J. R. (2009). Animal Spirits: How Human Psychology Drives the Economy, and Wby It Matters for Global Capitalism, Princeton University Press, Princeton.

Al Halbusi, H., \& Tehseen, S. (2018). The Effect of Electronic Word-Of-Mouth (EWOM) on brand image and purchase intention: a conceptual paper. SocioEconomic Challenges, 3(2), 83-94. https://doi.org/10.21272/sec.3(2).83-94.2018

Baburina, N. A., Tarkhanova, E. A., \& Fedorova, O. B. (2017). Innovational approaches to attracting people savings in the modern economy. Marketing and Management of Innovations, (3), 187-197. https://doi.org/10.21272/mmi.2017.3-18

Bagmet, K., Bouheni, F.B., \& Obeid, H. (2015). Bank-insurance integration level in Ukraine: Science-methodological approach. Journal of Applied Business Research, 31(6), 2253-2267. https://doi.org/10.19030/jabr.v31i6.9481

Bagmet, K.V. (2011). Risk management within bank insurance system. Actual Problems of Economics, 118(4), $203-210$.

Balas, A.N., \& Kaya, H.D. (2019). The global economic crisis and retailers' security concerns: the trends. SocioEconomic Challenges, 3(2), 5-14. https://doi.org/10.21272/sec.3(2).5-14.2019.

Beveridge, W. H. (1909). Unemployment: A Problem of Industry, Longmans Green, London.

Bilan, Y., Brychko, M., Buriak, A., \& Vasilyeva, T. (2019). Financial, business and trust cycles: the issues of synchronization, Zbornike radova Ekonomskog fakulteta u Rijeci, 37(1), 113-138, https://doi.org/10.18045/zbefri.2019.1.113. 
Bilan, Y., Mishchuk, H., \& Dzhyhar, T. (2017). Human capital factors and remuneration: Analysis of relations, modelling of influence. Business: Theory and Practice, 18, 208-214. https://doi.org/10.3846/btp.2017.022

Bilan, Y., Raišienè, A. G., Vasilyeva, T., Lyulyov, O., \& Pimonenko, T. (2019). Public governance efficiency and macroeconomic stability: Examining convergence of social and political determinants. Public Policy and Administration, 18(2), 241-255. https://doi.org/10.13165/VPA-19-18-2-05.

Bilan, Y., Rubanov, P., Vasylieva, T., \& Lyeonov, S. (2019). The influence of industry 4.0 on financial services: Determinants of alternative finance development. Polish Journal of Management Studies, 19(1), 70-93. https://doi.org/10.17512/pjms.2019.19.1.06

Bilan, Y., Vasilyeva, T., Lyulyov, O., \& Pimonenko, T. (2019). EU vector of Ukraine development: Linking between macroeconomic stability and social progress. International Journal of Business and Society, 20(2), 2019, 433-450

Bilan, Y., Vasylieva, T., Lyeonov, S., \& Tiutiunyk, I. (2019). Shadow economy and its impact on demand at the investment market of the country. Entrepreneurial Business and Economics Review, 7(2), 27-43. https://doi.org/10.15678/EBER.2019.070202

Blajer-Gołębiewska, A., \& Kos, M. (2016), Investors are more sensitive to information about financial rather than ethical reputation of a company: evidence from an experimental study. Economics and Sociology, 9(1), 11-22. https://doi.org/10.14254/2071-789X.2016/9-1/1

Blajer-Gołębiewska, A., \& Kos, M. (2016), Investors are more sensitive to information about financial rather than ethical reputation of a company: evidence from an experimental study. Economics and Sociology, 9(1), 11-22. https://doi.org/10.14254/2071-789X.2016/9-1/1

Boyarko, I.M., \& Samusevych, Y.V. (2011). Role of intangible assets in company's value creation. Actual Problems of Economics, 117(3), 86-94.

Buriak, A., Vasylieva, T., \& Lyeonov S. (2015). Systemically important domestic banks: an indicator-based measurement approach for the Ukrainian banking system. Prague Economic Papers, 6(24), 715-728, https://doi.org/10.18267/j.pep.531.

Calvo, G., \& Mendoza, E. (2000). Rational contagion and the globalization of securities markets, Journal of International Economics, 51 (1), 79-113, https://doi.org/10.1016/s0022-1996(99)00038-0.

Charemza, W., Makarova, S., Prytula, Ya., Raskina, J., \& Vymyatnina, Yu. (2009). A Small Forward-Looking InterCountry Model (Belarus, Russia and Ukraine). Economic Modelling, 26(6), 1172-1183.

Clark, J.M. (1917). Business Acceleration and the Law of Demand: A Technical Factor in Economic Cycles, Journal of Political Economy, 25 (1), 217-235, https://doi.org/10.1086/252958.

Djalilov, K., Lyeonov, S., \& Buriak, A. (2015). Comparative studies of risk, concentration and efficiency in transition economies. Risk Governance and Control: Financial Markets and Institutions, 5(4CONT1), 178-187.

Dzikevičius A, Vetrov J (2012) Stock Market Analysis Through Business Cycle Approach. Business: Theory and Practice, 13(1): 36-42. https://doi.org/10.3846/btp.2012.04

Dzikevičius, A., \& Vetrov, J. (2013) Investment portfolio management using the business cycle approach. Business: Theory and Practice, 14(1), 57-63. https://doi.org/10.3846/btp.2013.07

Filipishyna, L., Bessonova, S., \& Venckeviciute, G. (2018). Integral assessment of developmental stability: cases of Lithuania and Ukraine. Entrepreneurship and Sustainability Issues, 6(1), 87-99. https://doi.org/10.9770/jesi.2018.6.1(7)

Gazda, J. (2008). Testing Real Business Cycle Models in Polish Economy. Journal of International Studies, 1(1), $27-32$.

Gazda, J. (2010). Real Business Cycle Theory - Methodology and Tools. Economics \& Sociology, 3(1), 42-48.

Hadbaa, H., \& Boutti, R. (2019). Behavioral Biases Influencing the Decision Making of Portfolio Managers of Capital Securities and Traders in Morocco. Financial Markets, Institutions and Risks, 3(1), 92-105. http://doi.org/10.21272/fmir.3(1).92-105.2019.

Horsch, A., Sysoyeva, L., \& Bogma, S. (2018). Deposit insurance systems of post-Soviet countries: A comparative analysis. Journal of International Studies, 11(4), 22-44. https://doi.org/10.14254/2071-8330.2018/11-4/2

Kahneman, D., \& Tversky, A. (1979). Prospect theory: An analysis of decision under risk. Econometrica, 47, 263-291, https://doi.org/10.2307/1914185. 
Kamińska T. (2016). Is the 'Flying Geese' Paradigm useful to explain advancement in the European Union by means of FDI phenomenon?. Journal of International Studies, 9(2), 9-24. https://doi.org/10.14254/20718330.2016/9-2/1.

Kaminsky, G., \& Reinhart, C. (2000). On crises, contagion, and confusion. Journal of International Economics, 51(1), 145168.

Kaminsky, G., Reinhart, C., \& Vegh, C. (2003). The unholy trinity of financial contagion. Journal of Economic Perspectives, 17(4), 51-74, https://doi.org/10.3386/w10061.

Kapidani, M., Luci, E. (2019). The Effects on innovation from financial sector development: evidence from developing countries. Journal of Competitiveness, 11(2), 84-94. https://doi.org/10.7441/joc.2019.02.06

Kendiukhov, I., \& Tvaronavičienè, M. (2017). Managing innovations in sustainable economic growth. Marketing and Management of Innovations, (3), 33-42. https://doi.org/10.21272/mmi.2017.3-03

Keynes, J. M. (1936). The General Theory of Employment, Interest, and Money. New York.

Kolosok, S., \& Myroshnychenko, I. (2015). Structural change and business cycle dynamics in transition economies. Journal of Applied Economic Sciences, 10(1), 128-141.

Korauš, A., Gombár, M., Kelemen, P., \& Backa, S. (2019). Awareness of security risks associated with payment systems analyzed by the methods of multidimensional statistics. Journal of Security and Sustainability Issues, 8(4), 687-703. https://doi.org/10.9770/jssi.2019.8.4(12)

Kostyuchenko, N., Starinskyi, M., Tiutiunyk, I., \& Kobushko, I. (2018). Methodical approach to the assessment of risks connected with the legalization of the proceeds of crime. Montenegrin Journal of Economics, 14(4), 023-043. https://doi.org/10.14254/1800-5845/2018.14-4.2

Kovacic, Z. J., \& Vilotic, M. (2017). Characterising and testing European business cycles asymmetry. Equilibrium. Quarterly Journal of Economics and Economic Policy, 12(3), 453-468. https://doi.org/10.24136/eq.v12i3.24

Kozmenko, O., \& Roienko, V. (2013). Evaluation and use of indicators of insurance companies' investment activities. Investment Management and Financial Innovations, 10(3), 98-105. https://doi.org/10.21511/imfi.10(3).2013.01

Kozmenko, O., Merenkova, O., \& Boyko, A. (2009). The analysis of insurance market structure and dynamics in Ukraine, Russia and European insurance and reinsurance federation (CEA) member states. Problems and Perspectives in Management, 7(1), 29-39. https://doi.org/10.21511/ppm.7(1).2009.01

Kuzmenko, O., \& Kyrkach, S. (2014). The use of regression analysis in the financial planning of banks, mathematical formalization of the stages of financial planning in banks. Banks and Bank Systems, 9(1), 120-126.

Kuzmenko, O.V., \& Koibichuk, V.V. (2018). Econometric modeling of the influence of relevant indicators of gender policy on the efficiency of a banking system. Cybernetics and Systems Analysis, 5, 3-12

Lazányi K., \& Bilan Y. (2017). Generation z on the labour market - do they trust others within their workplace?. Polish Journal of Management Studies, 16(1), 78-93. https://doi.org/10.17512/pjms.2017.16.1.07

Leonov, S., Yarovenko, H., Boiko, A., \& Dotsenko, T. (2019). Information system for monitoring banking transactions related to money laundering. CEUR Workshop Proceedings, 2422, 297-307.

Leonov, S.V., Vasylyeva, T.A., \& Tsyganyuk, D.L. (2012). Formalization of functional limitations in functioning of coinvestment funds basing on comparative analysis of financial markets within FM CEEC. Actual Problems of Economics, 134(8), 75-85.

Leśniewski, M.A. (2019). Humanistic - behavioral - cultural competitive advantage of the enterprises - concept models. Business Ethics and Leadership, 3(1), 34-43. http://doi.org/10.21272/bel.3(1). 34-43.2019.

Lobanova, J., Kračun, D., \& Kavkler, A. (2018). Effects of cross-border mergers and acquisitions on GDP per capita and domestic investment in transition countries. Journal of Business Economics and Management, 19(1), 124-137. https://doi.org/10.3846/16111699.2017.1408677

Luchko, M., Lew, G., Ruska, R., \& Vovk, I. (2019). Modelling the Optimal Size of Investment Portfolio in a NonState Pension Fund. Journal of International Studies, 12(1), 239-252.

Lyulyov, O., Chygryn, O., \& Pimonenko, T. (2018). National brand as a marketing determinant of macroeconomic stability. Marketing and Management of Innovations, 3, 142-152. http://doi.org/10.21272/mmi.2018.3-12

Mazur, B. (2017). Probabilistic predictive analysis of business cycle fluctuations in Polish economy. Equilibrium. Quarterly Journal of Economics and Economic Policy, 12(3), 435-452. https://doi.org/10.24136/eq.v12i3.23 
Mostenska, T., \& Bilan, Y. (2015). Sustainable development through enhanced social responsibility. Journal of Security and Sustainability Issues, 4(3), 536-551. https://doi.org/10.9770/jssi.2015.4.3(4)S

Olczyk, M., \& Kordalska, A. (2018). Growth and structural changes in transition countries: the chicken or the egg?. Journal of Business Economics and Management, 19(3), 544-565. https://doi.org/10.3846/jbem.2018.6580

Oliinyk, V. (2018). Optimal Management of GDP Components. Journal of Advanced Research in Law and Economics, 9(2), 603-614. https://doi.org/10.14505/jarle.v9.2(32).24.

Onyshchenko, V., Chen B. X. (2017). Influence of state banks on economic growth: a cross-country analysis. Financial Markets, Institutions and Risks, 1(3), 44-54. https://doi.org/10.21272/ fmir.1(3).44-54.2017

Petrushenko, Y.M., Kostyuchenko, N., Smolennikov, D., \& Vorontsova, A. (2017). Impact of the participatory financing of international development projects on social capital of the local communities. Problems and Perspectives in Management, 15(3), 183-192. https://doi.org/10.21511/ppm.15(3-1).2017.02

Pigou, A.C. (1927). Industrial Fluctuations. London, MacMillan.

Prince, T. (2017). Behavioral finance and the business cycle. Business Ethics and Leadership, 1(4), 28-48. https://doi.org/10.21272/bel.1(4).28-48.2017

Rahman, A., Rahman, M.T., \& Ključnikov, A. (2016). Collateral and SME financing in Bangladesh: an analysis across bank size and bank ownership types. Journal of International Studies, 9(2), 112-126. doi: 10.14254/2071$8330.2016 / 9-2 / 8$

Sebestova, J., Majerova, I., \& Szarowska, I. (2018). Indicators for assessing the financial condition and municipality management. Administratie si Management Public, (31), 97-110, https://doi.org/10.24818/amp/2018.31-07

Simionescu, M. (2018). Effects of European economic integration on foreign direct investment: The case of Romania. Economics and Sociology, 11(4), 96-105. https://doi.org/10.14254/2071-789X.2018/11-4/6.

Simionescu, M. (2019). The evolution of the Romanian insurance market after 2000. Economics, Management and Sustainability, 4(1), 21-28. https://doi.org/10.14254/jems.2019.4-1.2

Skvarciany, V., Jurevičiene, D., Iljins, J., \& Gaile-Sarkane, E. (2018). Factors influencing a bank's competitive ability: the case of Lithuania and Latvia. Oeconomia Copernicana, 9(1), 7-28. https://doi.org/10.24136/oc.2018.001

Stremmel, H., Zsamboki, B. (2015). The Relationship between Structural and Cyclical Features of the EU Financial Sector. ECB Working Paper No. 1812.

Swiatkiewicz, O. (2018). Market Communication: Ethical and Praxeological Dimensions. Economics and Sociology, 11(2), 184-199. https://doi.org/10.14254/2071-789X.2018/11-2/13

Trojanek, R. (2010). Cyclical Behaviour of Residential Markets. Journal of International Studies, 3 (1), 28-35.

Valaskova, K., Kliestik, T., \& Kovacova, M. (2018). Management of financial risks in Slovak enterprises using regression analysis. Economic Copernicana, 9(1), 105-121. https://doi.org/10.24136/oc.2018.006

Vasilyeva, T. A., Leonov, S. V., \& Lunyakov, O. V. (2013). Analysis of internal and external imbalances in the financial sector of ukraine's economy. Actual Problems of Economics, 150(12), 176-184.

Vasylyeva, T. A., Leonov, S. V., \& Lunyakov, O. V. (2014). Countercyclical capital buffer as a macroprudential tool for regulation of the financial sector. Actual Problems of Economics, 158(8), 278-283.

Vasylyeva, T.A., \& Chmutova, I.M. (2015). Empirical model of a bank life cycle. Actual Problems of Economics, 172(10), 352-361.

Vasylyeva, T.A., Sysoyeva, L., \& Vysochyna, A. (2016). Formalization of factors that are affecting stability of Ukraine banking system. Risk Governance and Control: Financial Markets and Institutions, 6(4), 7-11. https://doi.org/10.22495/rcgv6i4art1

Vejačka, M., \& Štofa, T. (2017). Influence of security and trust on electronic banking adoption in Slovakia: Ekonomie a Management, 20(4), 135-150. https://doi.org/10.15240/tul/001/2017-4-010

Yevdokimov, Y., Melnyk, L., Lyulyov, O., Panchenko, O., \& Kubatko, V. (2018). Economic freedom and democracy: Determinant factors in increasing macroeconomic stability. Problems and Perspectives in Management, 16(2), 279290. https://doi.org/10.21511/ppm.16(2).2018.26

Zachko, O., Golovatyi, R., \& Yevdokymova, A. (2017). Development of a simulation model of safety management in the projects for creating sites with mass gathering of people. Eastern-European Journal of Enterprise Technologies, 2(3-86), 15-24. https://doi.org/10.15587/1729-4061.2017.98135 


\section{APPENDIX A}

Table A.1

Cyclical indicators of trust in the financial sector of Ukraine

\begin{tabular}{|c|c|c|c|c|c|c|c|c|c|c|c|c|c|c|c|}
\hline $\operatorname{Lag}$ & $\mathrm{DP}_{\mathrm{r}}$ & $\mathrm{RW}_{\mathrm{i}}$ & $\mathrm{MS}_{\mathrm{e}}$ & $\mathrm{UE}_{\mathrm{r}}$ & $\mathrm{I}_{\mathrm{r}}$ & $\mathrm{L}_{\mathrm{NBU}}$ & $\mathrm{ER}_{\mathrm{UAH}}$ & EL & $\mathrm{SED}$ & $\operatorname{Re}_{\mathrm{GDP}}$ & IR & IPS & MPS & APFS & $\triangle \mathrm{PPES}$ \\
\hline-4 & 0,420 & $-0,410$ & $-0,373$ & 149 & 220 & $-0,094$ & & 014 & 191 & 033 & 246 & 167 & 169 & 144 & 10 \\
\hline-3 & 0944 & $-0,413$ & $-0,316$ & 140 & 0024 & 3 & & 0,014 & in & $-0,041$ & 5 & 52 & 4 & 8 & 1 \\
\hline-2 & 0,039 & 426 & $-0,381$ & 077 & 167 & 0,386 & & 055 & 11 & 067 & $-0,205$ & 0,099 & 113 & 063 & 010 \\
\hline-1 & 100 & סדתי & | & Sou & 11 & & & 104 & & TI & 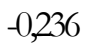 & 0,11 & $-0,115$ & ד, ד, & , \\
\hline 0 & 406 & 310 & $-0,188$ & 558 & 294 & 037 & 0,091 & 046 & 100 &, 489 & $-0,270$ & $-0,227$ & $-0,060$ &, 157 & $-0,198$ \\
\hline 1 & 2 & 10 & 0,179 & 14 & | & 0102 & 0 & $\overline{\mathrm{O}}$ & 2 & 9 & 97 & 0,166 & $-0,073$ & 8 & $-0,086$ \\
\hline 2 & 0,131 & 088 & 0,233 & 0,048 & 0,155 & & & $-0,278$ & 0,033 & $-0,104$ & $-0,279$ & $-0,059$ & 0,151 & $-0,478$ & $-0,038$ \\
\hline 3 & w & $-0,010$ & 0,340 & 0,084 & 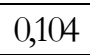 & 7 & 0 & $-0,307$ & 1 & $-0,124$ & $-0,331$ & $-0,123$ & 0,035 & 29 & 0,044 \\
\hline 4 & 0,329 & 0,131 & 0,398 & 0,163 & 0,150 & 0,340 & 0,488 & $-0,349$ & $-0,153$ & $-0,416$ & $-0,275$ & $-0,230$ & $-0,035$ & $-0,215$ & $-0,209$ \\
\hline & $\mathrm{Ld}$ & $\mathrm{L}$ & 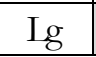 & $C_{4}$ & $\mathrm{C}$ & $T$ & $T$ & $\mathrm{Ig}$ & $\mathrm{Ld}$ & Co & $\mathrm{Ig}$ & $\mathrm{Ig}$ & $\mathrm{Ld}$ & $g$ & $g$ \\
\hline
\end{tabular}

Notes: GDP - Real GDP; RW - Real wage index; AMS $_{\mathrm{e}}$ - Average monthly salary per one employee; $\mathrm{UE}_{\mathrm{r}}$ - Unemployment rate; $\mathrm{I}_{\mathrm{r}}$ - Inflation rate; $\mathrm{RL}_{\mathrm{NBU}}$ - Volume of refinance loans granted by the National Bank of Ukraine; ER $\mathrm{UAH}_{\mathrm{U}}$ - Weighted average hryvnia exchange rate in the Ukrainian interbank foreign exchange market; REL - Volume of residential real estate loans in total gross loans of the banking sector; GED Gross external debt; Re GDP - Level of GDP redistribution through consolidated budget of Ukraine; IR International reserves; APS - Average propensity to save; MPS - Marginal propensity to save; APFS Average propensity to financial savings; MPFS - Marginal propensity to financial savings; Ld - leading (signal); Co - coincident; Lg - lagged.

- common to financial sector of the economy, banking system and non-banking financial and credit system 
Cyclical indicators of trust in the banking system of Ukraine

\begin{tabular}{|c|c|c|c|c|c|c|c|c|c|c|c|c|c|c|c|}
\hline $\mathrm{Lag}$ & $\mathrm{GDP}_{\mathrm{r}}$ & $\mathrm{RW}_{\mathrm{i}}$ & $\mathrm{AMS}_{\mathrm{e}}$ & $\mathrm{UE}_{\mathrm{r}}$ & $\mathrm{I}_{\mathrm{r}}$ & $\mathrm{RL}_{\mathrm{NBU}}$ & $\mathrm{ER}_{\mathrm{UAH}}$ & REL & GED & $\operatorname{Re}_{\text {GDP }}$ & $\mathrm{IR}$ & APS & MPS & APFS & MPFS \\
\hline 4 & 0,531 & $-0,416$ & $-0,073$ & 0,286 & 0,397 & 0,110 & 0,130 & $-0,195$ & 0,228 & $-0,090$ & $-0,515$ & 0,117 & $-0,338$ & 0,038 & $-0,408$ \\
\hline-3 & 0,092 & $-0,444$ & $-0,047$ & 0,205 & 0,016 & 0,116 & 0,175 & $-0,207$ & 0,199 & $-0,113$ & $-0,446$ & $-0,211$ & $-0,413$ & 0,144 & $-0,109$ \\
\hline-2 & 0,090 & $-0,473$ & $-0,083$ & 0,089 & 0,250 & 0,034 & 0,176 & $-0,149$ & 0,126 & 0,066 & $-0,424$ & 0,042 & 0,113 & $-0,125$ & 0,009 \\
\hline-1 & 0,189 & $-0,448$ & $-0,041$ & 0,301 & 0,329 & 0,225 & 0,208 & $-0,038$ & $-0,065$ & 0,200 & $-0,481$ & 0,058 & $-0,098$ & 0,105 & $-0,006$ \\
\hline 0 & 0,538 & $-0,337$ & 0,072 & 0,516 & 0,317 & 0,175 & 0,307 & $-0,120$ & 0,070 & $-0,686$ & $-0,438$ & $-0,404$ & $-0,126$ & $-0,381$ & $-0,365$ \\
\hline 1 & $-0,002$ & $-0,103$ & 0,184 & 0,113 & $-0,036$ & 0,198 & 0,355 & $-0,276$ & 0,058 & $-0,025$ & $-0,301$ & $-0,165$ & $-0,073$ & $-0,375$ & $-0,087$ \\
\hline 2 & 0,131 & $-0,087$ & 0,238 & 0,048 & 0,156 & 0,328 & 0,388 & $-0,286$ & 0,037 & $-0,110$ & $-0,284$ & $-0,058$ & 0,150 & $-0,485$ & $-0,038$ \\
\hline 3 & 0,001 & $-0,010$ & 0,353 & 0,086 & 0,105 & 0,534 & 0,435 & $-0,315$ & $-0,097$ & $-0,129$ & $-0,336$ & $-0,123$ & 0,034 & $-0,336$ & 0,043 \\
\hline 4 & 0,330 & 0,130 & 0,403 & 0,165 & 0,151 & 0,344 & 0,493 & $-0,357$ & $-0,150$ & $-0,419$ & $-0,281$ & $-0,229$ & $-0,036$ & $-0,222$ & $-0,209$ \\
\hline & $\overline{\mathrm{Co}}$ & $\overline{\mathrm{Ld}}$ & $\mathrm{Ig}$ & $\mathrm{Co}$ & $\mathrm{Ld}$ & $\mathrm{Ig}$ & $\mathrm{Ig}$ & $\mathrm{Ig}$ & $\mathrm{Ld}$ & $\overline{\mathrm{Co}}$ & $\overline{\mathrm{Ld}}$ & $\mathrm{Co}$ & $\mathrm{Ld}$ & $\mathrm{Ig}$ & $\mathrm{Ld}$ \\
\hline
\end{tabular}

Notes: GDP $\mathrm{r}$ - Real GDP; RW - Real wage index; $\mathrm{AMS}_{\mathrm{e}}-$ Average monthly salary per one employee; $\mathrm{UE}_{\mathrm{r}}$ - Unemployment rate; $\mathrm{I}_{\mathrm{r}}$ - Inflation rate; $\mathrm{RL}_{\mathrm{NBU}}$ - Volume of refinance loans granted by the National Bank of Ukraine; ER $\mathrm{UAH}_{\mathrm{U}}$ - Weighted average hryvnia exchange rate in the Ukrainian interbank foreign exchange market; REL - Volume of residential real estate loans in total gross loans of the banking sector; GED Gross external debt; Re GDP - Level of GDP redistribution through consolidated budget of Ukraine; IR International reserves; APS - Average propensity to save; MPS - Marginal propensity to save; APFS Average propensity to financial savings; MPFS - Marginal propensity to financial savings; Ld - leading (signal); Co - coincident; Lg - lagged.

- common to financial sector of the economy, banking system and non-banking financial and credit system 
Table A.3

Cyclical indicators of trust in the non-banking financial and credit system of Ukraine

\begin{tabular}{|c|c|c|c|c|c|c|c|c|c|c|c|c|c|c|c|}
\hline $\operatorname{Lag}$ & $\mathrm{GDP}_{\mathrm{r}}$ & $\mathrm{RW}_{\mathrm{i}}$ & $\mathrm{AMS}_{\mathrm{e}}$ & $\mathrm{UE}_{\mathrm{r}}$ & $I_{r}$ & $\mathrm{RL}_{\mathrm{NBU}}$ & $\mathrm{ER}_{\mathrm{UAH}}$ & REL & $\mathrm{BED}$ & $\mathrm{e}_{\mathrm{GDP}}$ & $\mathrm{IR}$ & APS & MPS & APFS & MPFS \\
\hline 4 & 102 & 103 & $-0,673$ & 0,133 &, 072 & $-0,557$ & $-0,574$ & 0,797 & $-0,561$ & 637 & 0,512 & 0,105 & 0,010 & 933 & 0,051 \\
\hline-3 & $-0,158$ & $-0,168$ & $-0,658$ & 0,178 & 109 & $-0,557$ & $-0,574$ & 0,831 & $-0,593$ & 541 & 0,487 & 0,017 & $-0,047$ & 0,891 & 0,079 \\
\hline-2 & $-0,135$ & $-0,198$ & $-0,635$ & 0,161 & $-0,067$ & $-0,534$ & $-0,571$ & 0,845 & $-0,601$ & 0,565 & 0,483 & 0,037 & 0,006 & 0,889 & 0,100 \\
\hline-1 & $-0,102$ & $-0,221$ & $-0,613$ & 0,217 & $-0,045$ & $-0,496$ & $-0,565$ & 0,859 & $-0,604$ & 0,572 & 0,481 & 0,047 & $-0,033$ & 0,889 & 0,098 \\
\hline 0 & 0,003 & $-0,297$ & $-0,611$ & 0,320 & $-0,052$ & $-0,518$ & $-0,576$ & 0,894 & $-0,554$ & 0,064 & 0,458 & $-0,158$ & $-0,057$ & 0,621 & 0,021 \\
\hline 1 & 0,000 & $-0,212$ & $-0,589$ & 0,133 & $-0,116$ & $-0,521$ & $-0,579$ & 0,866 & $-0,519$ & 0,653 & 0,512 & $-0,153$ & 0,005 & 0,768 & 0,067 \\
\hline 2 & $-0,003$ & $-0,139$ & $-0,592$ & $-0,026$ & $-0,104$ & $-0,519$ & $-0,586$ & 0,880 & $-0,468$ & 0,661 & 0,555 & $-0,074$ & 0,083 & 0,755 & 0,066 \\
\hline 3 & $-0,109$ & $-0,036$ & $-0,580$ & $-0,178$ & $-0,083$ & $-0,502$ & $-0,592$ & 0,879 & $-0,434$ & 0,627 & 0,585 & $-0,044$ & 0,095 & 0,783 & 0,088 \\
\hline 4 & $-0,075$ & 0,094 & $-0,583$ & $-0,291$ & $-0,078$ & $-0,518$ & $-0,595$ & 0,862 & $-0,357$ & 0,405 & 0,648 & $-0,032$ & 0,095 & 0,796 & 0,065 \\
\hline & $\mathrm{Ld}$ & Co & $\mathrm{Ld}$ & Co & $\mathrm{Ig}$ & $\mathrm{Ld}$ & $\mathrm{Ig}$ & Co & Ld & $\mathrm{Ig}$ & $\mathrm{Ig}$ & Co & $\mathrm{Ig}$ & Ld & Ld \\
\hline
\end{tabular}

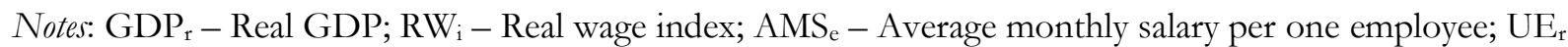
- Unemployment rate; $\mathrm{I}_{\mathrm{r}}$ - Inflation rate; $\mathrm{RL}_{\mathrm{NBU}}$ - Volume of refinance loans granted by the National Bank of Ukraine; ER $\mathrm{UAH}_{\mathrm{UA}}$ - Weighted average hryvnia exchange rate in the Ukrainian interbank foreign exchange market; REL - Volume of residential real estate loans in total gross loans of the banking sector; GED Gross external debt; Re GDP - Level of GDP redistribution through consolidated budget of Ukraine; IR International reserves; APS - Average propensity to save; MPS - Marginal propensity to save; APFS Average propensity to financial savings; MPFS - Marginal propensity to financial savings; Ld - leading (signal); Co - coincident; Lg - lagged.

- common to financial sector of the economy, banking system and non-banking financial and credit system 